\title{
Studies on Cultural, Morphological Variability in Isolates Fusarium solani, Incitant of Dry Root-rot of Sweet Orange
}

\author{
S.A. Padvi ${ }^{1}$ *, P.B. Khaire ${ }^{2}$, V.H. Bhagat ${ }^{2}$ and D.G. Hingole ${ }^{1}$ \\ ${ }^{1}$ Department of Plant Pathology, College of Agriculture, Badnapur, 431202 (M.S), India \\ ${ }^{2}$ College of Agriculture Naigaon (Bz.), Nanded, 431709 (M.S), India \\ *Corresponding author
}

\section{A B S T R A C T}

\section{Keywords}

Fusarium solani,

Dry root rot,

Variability, Sweet orange

Article Info

Accepted:

26 June 2018

Available Online:

10 July 2018
Eight isolates of Fusarium solani incident of dry root-rot in sweet orange were studied for its cultural and morphological variability. The $F$. solani isolates, AFs, JFs, SFs, BFs, GFs, PFs, AmFs and GhFs grow more than $90 \mathrm{~mm}$ after 7 days of inoculation and considered as fast growing category. The size of micro conidia ranged from 3- $4 \times 1-2 \mu \mathrm{m}$ to $11-10 \times 1-2 \mu \mathrm{m}$. and the size of macro conidia ranged from 13-15 X 3-4 $\mu \mathrm{m}$ to $24-26 \times 4-5 \mu \mathrm{m}$. The number of septa in macro conidia and in micro conidia is $2-4$ and $0-1$, respectively and conidia are hyaline. The macro conidia is sickle shaped with blunt end and micro conidia is round to oval shaped. Intercalary and terminal chlamydospores were observed in all the $F$. solani isolates.

\section{Introduction}

Sweet orange is one of the important citrus fruits that constitute nearly $20 \%$ of the total citrus production in India. Andhra Pradesh is one of the important citrus producing states in the country with a total area of about 1.66 lakh hectares and an annual production of 2.23 lakh tones. Sweet orange is affected by several soil borne pathogens like Fusarium, Rhizoctonia, and Diplodia species causing root-rot disease both in nursery and main field affecting life and production of acid lime. Among these, Fusarium solani causes dry root-rot in sweet orange seedlings and also in the developed plants. In nature, plant pathogens exist as different strains that exhibit variation in their morphological and cultural characters, pathogenicity and virulence. To understand the present plant disease situations and to predict the possible future development it is essential to learn as much as possible about the variability in fungi that are pathogenic to plants. Morphological and pathogenic variations are known in many fungal pathogens (Kumar et al., 1995). Due to variation in the distribution of $F$. solani across environments, it is important to know which isolate is most virulent within a given species especially for germplasm evaluations where 
the goal is to identify genetic resistance to highly virulent isolates. Keeping in view, present investigation was taken up to study the variability in cultural and morphological characters of $F$. solani isolates.

\section{Materials and Methods}

\section{Morphological and cultural studies}

The Morphological and cultural characters of Fusarium solani was studied with dry root rot of Sweet orange. Basic cultural characteristics were studied following the methods of Sneh et al; (1991). The isolates were grown on PDA by inoculating $5 \mathrm{~mm}$ disc of the fungus at the centre of the petriplate. The inoculum disc was taken with the help of cork borer from the edge of the actively growing culture. Plates were incubated at $25 \pm 2{ }^{\circ} \mathrm{C}$ in BOD. Observations on colony growth, diameter of the colony; colony color and amount of sporulation in respect of all the isolates were recorded.

\section{Cultural characteristics}

Basic cultural characteristics of test pathogen Fusarium solani was studied following the methods of Rao and Krishnappa (1997). To study the various cultural characteristics of different isolates of Fusarium solani isolated from diseased samples collected from collected from different locations. These isolates were grown on PDA medium. The PDA media was sterilized in Autoclave at 15 $\mathrm{lbs} / \mathrm{inch}^{2}$ pressure for minutes. Twenty $\mathrm{ml}$ of PDA medium was poured in to $90 \mathrm{~mm}$ diameter petriplates. After solidification $5 \mathrm{~mm}$ disc of Fusarium solani from actively growing culture were at using a sterile cork borer and a single disc was placed upside down at the centre of petri dish. Each isolate was replicated thrice and plates were incubated at $27 \pm 1^{0} \mathrm{C}$. The measurement of colony diameter was recorded 7 days of inoculation. The cultural characteristics viz, colony diameter, colony colour and amount of sporulation were recorded.

\section{Morphological characteristics}

Morphological variations of the different eight isolates of Fusarium solani were studied. To study the morphological characters a small amount of pure culture was taken using a sterile needle and transferred on to a clean glass slide. The cultures were taken from four portions of the culture plate. Two at the right angle to each other, one from very close to the inoculation point and another midpoint of radius. Total three culture plates of each isolate were used for morphological studies 6 days after inoculation. The culture was stained with $0.1 \%$ lactophenol cotton blue and observed for micro conidia, macro conidia micro conidial size was measured with the help of an ocular micrometer after calibrating the microscope with 100 conidia in each replication. Macro conidia length and breadth of 100 conidia for each of three replications of all the isolates were measured using 15 days old culture. While dimension of chlamydospores were also recorded using 25 days old culture.

\section{Results and Discussion}

\section{Cultural and morphological characters}

Morphogenic diversity of Fusarium solani was studied based on cultural and morphological characters of isolates.

\section{Cultural studies}

The cultural character of different isolates from diseased specimen collected from Jalna and Aurangabad districts of Marathwada region was used for the study. The observation recorded were mycelium colour, substrate colour, colony texture, colony pattern and sporulation etc. The observations on cultural characteristics of eight isolates of Fusarium solani given in (Table 1). 


\section{Mycelial colour}

Observation for mycelium colour were taken and found distinct differences among different isolates. The isolates were observed to have mycelium colour ranging from white to white cameo and cream. The isolates Aurangabad (AFs), Jalna (JFs), Soygoan (SFs) and Badnapur (BFs) were exhibited white colour of mycelium. While, three isolates viz., Gangapur (GFs), Pathan (PFs) and Ambad (AmFs) recorded white to cameo while remaining two isolates Ghansavangi (GhFs) and Badnapur (BFs) recorded cream colour of mycelium.

\section{Substrate colour}

The colour of substrate was observed from the bottom side of Petri dish based on the colony pigmentation. Seven day after inoculation the cultures were assigned to mulberry purple, violet, gold brown white to cream, crush violet, oriental perl and Vatican (Table 1). The substrate colour of Aurangabad (AFs) isolates was mulberry purple, while violet substrate was noticed with Jalna (JFs) isolates; golden brown colour of substrate was recorded with Ghansavangi (GhFs) isolates while Gangapur (GFs) and Soygoan (SFs) isolates recorded white cream to crushed violet colour respectively. The isolates Badnapur (BFs) reported oriental pearl colour of substrate. The isolates Ambad (AmFs) reported Vatican colour of substrate however Pathan (PFs) reported with colour and substrate.

While white to cameo mycelium colour was noticed in Gangapur (GFs), Ambad (AFs) and Paithan (PFs) isolates. In case of substrate colour all district exhibited different substrate colour like mulberry colour, violet, golden brown, white to cream, Vatican and oriental pearl etc.

Table.1 Cultural character of isolate of Fusarium solani on potato dextrose medium

\begin{tabular}{|c|c|c|c|c|c|}
\hline \multirow{2}{*}{$\begin{array}{l}\text { Sr. } \\
\text { No }\end{array}$} & \multirow{2}{*}{$\begin{array}{c}\text { Isolate } \\
\text { Code }\end{array}$} & \multicolumn{2}{|c|}{ Cultural characters } & \multirow{2}{*}{ Colony Texture } & \multirow{2}{*}{ Sporulation } \\
\hline & & Mycelium colour & $\begin{array}{l}\text { Substrate } \\
\text { colour }\end{array}$ & & \\
\hline 1 & AFs & White & $\begin{array}{l}\text { Mulberry } \\
\text { purple }\end{array}$ & $\begin{array}{l}\text { Very good growth suppressed, } \\
\text { dark color dots in the centre }\end{array}$ & +++ \\
\hline 2 & JFs & White & Violet & $\begin{array}{l}\text { growth suppressed dark color } \\
\text { dots in the centre }\end{array}$ & ++ \\
\hline 3 & GhFs & Cream & Gold brown & Fluffy & ++ \\
\hline 4 & GFs & White to Cameo & $\begin{array}{l}\text { White to } \\
\text { cream }\end{array}$ & Fluffy & ++ \\
\hline 5 & SFs & White & $\begin{array}{l}\text { Crushed } \\
\text { violet }\end{array}$ & $\begin{array}{l}\text { Scanty, fibrous, appraised to } \\
\text { substratum }\end{array}$ & ++ \\
\hline 6 & PFs & White to Cameo & - & Good scanty fibrous & ++ \\
\hline 7 & BFs & Cream & $\begin{array}{c}\text { Oriental } \\
\text { pearl }\end{array}$ & Growth suppressed but fast & +++ \\
\hline 8 & Am Fs & White to Cameo & Vatican & Good, fluffy, profusely dense & + \\
\hline \multicolumn{6}{|c|}{ 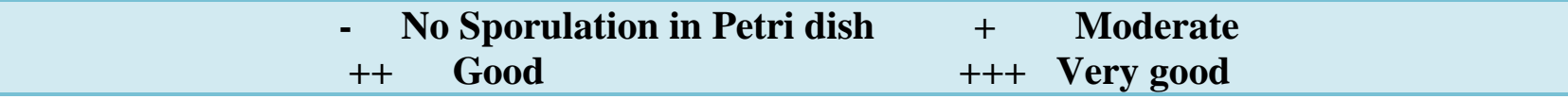 } \\
\hline
\end{tabular}

AFs- Aurangabad isolate, JFs- Jalna isolate, GhFs- Ghansavani isolate, GFs -Gangapur isolate, SFs - Soygaov isolate, PFs - Paithan isolate, BFs- Badnapur isolate, AmFs - Ambad isolate. 
Table.2 Size, shape, colour, septation of the macro conidia and micro conidia of different isolates of Fusarium solani

\begin{tabular}{|c|c|c|c|c|c|c|c|c|c|c|}
\hline \multirow{2}{*}{$\begin{array}{l}\text { Sr. } \\
\text { No. }\end{array}$} & \multirow{2}{*}{$\begin{array}{l}\text { Name of } \\
\text { Location }\end{array}$} & \multirow{2}{*}{ Isolates } & \multirow{2}{*}{$\begin{array}{c}\text { Macro } \\
\text { conidia } \\
(\mu \mathrm{m}) \\
\text { L X B }\end{array}$} & \multirow{2}{*}{$\begin{array}{c}\text { Micro } \\
\text { conidia } \\
(\mu \mathrm{m}) \\
\text { L X B }\end{array}$} & \multicolumn{2}{|c|}{ Septation } & \multicolumn{2}{|c|}{ Shape } & \multirow{2}{*}{ Colour } & \multirow{2}{*}{$\begin{array}{c}\text { Diameter of } \\
\text { chlamydospores } \\
(\mu \mathrm{m})\end{array}$} \\
\hline & & & & & Macro & Micro & $\begin{array}{l}\text { Macro } \\
\text { conidia }\end{array}$ & $\begin{array}{l}\text { Micro } \\
\text { conidia }\end{array}$ & & \\
\hline 1 & Aurangabad & AFs & $14-16$ X 2-4 & $4-5 \times 1-2$ & $3-4$ & $0-1$ & $\begin{array}{l}\text { Sickle shaped } \\
\text { with blunt } \\
\text { ends }\end{array}$ & $\begin{array}{c}\text { Round to } \\
\text { oval }\end{array}$ & Hyaline & $6.0-7.5$ \\
\hline 2 & Jalna & JFs & $23-26 \times 4-5$ & $6-7 \times 1-2$ & $2-4$ & $0-1$ & $\begin{array}{c}\text { Elongated } \\
\text { shaped with } \\
\text { blunt ends }\end{array}$ & $\begin{array}{c}\text { Round to } \\
\text { oval }\end{array}$ & Hyaline & $7.5-9.0$ \\
\hline 3 & Ghansavasngi & GhFs & $19-20 \times 3-4$ & $4-8 \times 1-2$ & $3-4$ & $0-1$ & Sickle shaped & $\begin{array}{c}\text { Round to } \\
\text { oval }\end{array}$ & Hyaline & $3.0-4.5$ \\
\hline 4 & Gangapur & GFs & $21-33 \times 2-4$ & $5-7 \times 2-3$ & $2-3$ & $0-1$ & Sickle shaped & $\begin{array}{c}\text { Round to } \\
\text { oval }\end{array}$ & Hyaline & $9.0-12.0$ \\
\hline 5 & Soygaov & SFs & $17-18 \times 3-4$ & $11-10 \times 1-2$ & $3-4$ & $0-1$ & $\begin{array}{l}\text { Sickle shaped } \\
\text { with blunt } \\
\text { ends }\end{array}$ & $\begin{array}{c}\text { Round to } \\
\text { oval }\end{array}$ & Hyaline & $6.0-8.0$ \\
\hline 6 & Paithan & PFs & $24-26 \times 4-5$ & $3-4 \times 1-2$ & $3-4$ & $0-1$ & Sickle shaped & $\begin{array}{c}\text { Round to } \\
\text { oval }\end{array}$ & Hyaline & $7.0-9.0$ \\
\hline 7 & Badnapur & $\mathrm{BFs}$ & $13-15 \times 3-4$ & $3-5 \times 1-2$ & $2-4$ & $0-1$ & Sickle shaped & $\begin{array}{c}\text { Round to } \\
\text { oval }\end{array}$ & Hyaline & $9.5-11.5$ \\
\hline 8 & Ambad & AmFs & $16-18 \times 4-5$ & $8-9 \times 3-4$ & $2-3$ & $0-1$ & Sickle shaped & $\begin{array}{c}\text { Round to } \\
\text { oval }\end{array}$ & Hyaline & $9.0-12.0$ \\
\hline
\end{tabular}




\section{Colony texture}

Observations for the texture of mycelial growth and colony appearance were also taken and found distinct differences among different isolates. Fluffy mycelial growth was noticed in isolates Ghansavangi (GhFs) and Gangapur (GFs). While very good growth suppressed dark coloured dot in centre was reported in Jalna (JFs) and Aurangabad (AFs) isolates. The isolates of Soygoan (SFs) and Paithan (PFs) where; looked slightly similar but different in mycelial scanty growth. In case of Ambad (AFs) and Badnapur (BFs) isolates growth of mycelium suppressed but fast and fluffy profusely dense respectively.

\section{Sporulation}

All the eight isolates exhibited a wide range of sporulation of the pathogen (Table 1). However isolates Aurangabad (AFs) and Badnapur (BFs) recorded very good (+++) sporulation and good (++) sporulation was recorded with isolates viz., Jalna (JFs), Ghansavangi (GhFs), Gangapur (GFs), Soygoan (SFs) and Paithan (PFs). The isolates Ambad (AFs) showed moderate (+) sporulation.

In the presents study the significant variation was noticed in cultural characters of eight different isolates with respective mycelium colour, substrate colour, sporulation etc. This is in agreement with earlier reports of Madhusudan et al., (2010), Ravichandran and Reddy (2012) were observed existence of wide variation among different isolates of Fusarium solani.

\section{Morphological studies}

The spores of pathogen were taken from pure culture and temporary slide mounts were prepared. Then they were observed under high power (45X). One hundred spores of pathogen were observed under microscope and measured using ocular and stage micrometer. The morphological characters the eight different isolate of Fusarium solani isolated from
Aurangabad and Jalna district shown significant variation in respect to size, shape, septation and colour of macro and micro conidia on PDA medium.

\section{Micro conidia}

The data presented in (Table 2) revealed that in all the eight isolates of the micro conidia were $0-1$ septed, hyline in colour and round to oval in shape. The size of micro conidia ranged from 3$4 \times 1-2 \mu \mathrm{m}$ to $11-10 \times 1-2 \mu \mathrm{m}$. The highest size of micro conidia was observed in isolates SFs. $(11-10 \times 1-2 \mu \mathrm{m})$. This was followed by isolate AmFs (8-9 X 3-4 $\mu \mathrm{m}) \mathrm{JFs}(6-7 \times$ X 1-2

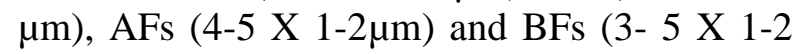
$\mu \mathrm{m})$ While smallest size micro conidia produce with PFs (3-4 X 1-2 $\mu \mathrm{m})$

\section{Macro conidia}

In all isolates 2-4 septate Macro conidia were observed. The Isolates, AFs, GhFs, SFs and PFs produced 3-4 septate macro conidia which were sickle shaped with bluent end (Table 2) While isolates viz JFs, GhFs, BFs and AmFs produced 2-4 septate macro conidia which were sickle shaped, expcept isolate JFs produced elongated shaped conidia with bluent ends. The size of macroconidia was varied from isolate to isolate. It was ranged from $13-15 \times 3-4 \mu \mathrm{m}$ to $24-26 \mathrm{X}$ 4-5 $\mu \mathrm{m}$. This was followed by isolate JFs 23-26 X4-5 $\mu \mathrm{m}$, GFs (24-33 X2-4 $\mu \mathrm{m})$, GhFs (19-20X

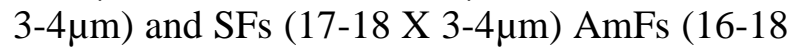
$\mathrm{X} 4-5 \mu \mathrm{m})$ and AFs (14-16 X2-4 $\mu \mathrm{m})$, While the least size macro conidia produced with isolate BFs $(13.15$ X $3.4 \mu \mathrm{m})$

\section{Chlamydospores}

The chlamydospores were observed 10 days old culture of all isolates they were either terminal or intercalary and formed singly or in pair but rarely in chain. Terminal Chlamydospores were prominent in isolates BFs, AmFs, and GFs. They were of variable in size and their dimension ranged from 3.0-12.0 $\mu \mathrm{m}$. Chlamydospores dimension were maximum in isolates AFs and GFs $(9.0-12.0 \mu \mathrm{m})$ followed 
by BFs, JFs, GFs, SFs and AFu, were as it was observed minimum in isolate $\mathrm{GhFs}(3.0-4.5 \mu \mathrm{m})$

Morphology of the pathogen in respect of septed mycelium, macro conidia and micro conidia and their dimensions are reported in present studies in conformity with Booth (1971), Ravi. Chandran and Reddi Kumar (2012), P. Madhusudhan et al., (2010) Who reported three distint type of conidial characteristics, morphology, pigmentation and sixe of macro conidia of different isolates of Fusarium solani.

\section{References}

Booth, C. (1971) The genus Fusarium, Common Wealth Mycological Institute Kew, Surrey, England: 44-45.

Burgess, L. W., P. E. Nelson and B. A. Summerell (1989) Variability and Stability of morphological characters of Fusarium oxysporum isolated from soils in Australia. Mycologia 81: 818-822.

Champawat, R. S. and V. N. Pathak (1989) Cultural Morphological and pathogenic variations in Fusarium oxysporum f.sp cumini. Indian Journal of Mycology and Plant Pathology 19: 178-183.

Desai A. G., S. R. S. Dange, D. S. Patel and D. B. Patel (2003) Variability in Fusarium oxysporum f.sp. ricini causing wilt of caster. Indian Journal of Mycology and Plant Pathology 37-41.

Gupta O. M, M. N. Khare and S. R. Kotasthane (1986) Variability among six isolates of Fusarium oxysporum f.sp. ceceri. Indian Phytopathology 39: 279-280.

Kumar S, Thind T S and Chander M. (1995) Morphogenic and pathogenic variations in Gloeosporium ampelogphagum. Indian Phytopathology 48: 331-334.

Mathur, B. L. and N. Prasad (1967) Studies on Fusarium wilt of cumin (cuminum cuminum L.) with reference to nature of variation in the causal organisms. Proceedings of National academy of science India 37:161-171.

Nirmaladevi, D., and C. Srinivas (2012). Cultural, morphological, and pathogenicity Variation in Fusarium oxysporum f. sp. lycopersici, causing wilt of tomato. Batman Univ. J. of Life Sci., 2(1).

Piplani S., P. D. Gemawat and N. Prasad (1985) Morphology and taxonomy of castor Fusarium. Indian Journal of Mycology and Plant Pathology 15: 42-47.

Ravi M. Chandran and M. Reddi Kumar (2012) Studies on cultural, morphological variability in isolates of Fusarium solani (Mart.) Sacc., incitant of dry root-rot of Citrus. Current Biotica 6(2): 152-162.

Shubatrivedi and Gurha S N (2007) Variability on Fusarium oxysporum f.sp ciceri isolates from Jhansi district of Bundelkhand, UP. Journal of Mycology Plant Pathology 37(2): 324-326.

Sreeja, S. J. (2014) Studies on Morphological, Cultural and Pathogenic Variability among the isolates of Fusarium spp. inciting cowpea wilt in Kerala. Life Sciences Leaflets vol. 52:12-15.

Young Sung Jung Young Tae Kim sung Joon You and Honey Gikim (1999) Mycological characteristics of Fusarium solani f. sp. pisi isolated from pea, ginseng and soybean in Korea. Plant Pathology Journal. 15 (1):44-47.

\section{How to cite this article:}

Padvi, S.A., P.B. Khaire, V.H. Bhagat and Hingole, D.G. 2018. Studies on Cultural, Morphological Variability in Isolates Fusarium solani, Incitant of Dry Root-rot of Sweet Orange. Int.J.Curr.Microbiol.App.Sci. 7(07): 3671-3676. doi: https://doi.org/10.20546/ijcmas.2018.707.423 